\title{
Article
}

\section{Oxidative and nitrosative stress induces peroxiredoxins in pancreatic beta cells}

\author{
A. Bast, G. Wolf, I. Oberbäumer, R. Walther \\ Department of Medical Biochemistry and Molecular Biology, Ernst-Moritz-Arndt-University Greifswald, Germany
}

\begin{abstract}
Aims/hypothesis. Insulin-producing beta cells are destroyed by oxidative and nitrosative stress during the pathogenesis of Type I (insulin-dependent) diabetes mellitus. These cells are more sensitive than others due to their deficiency of well known antioxidant enzymes like superoxide dismutase, glutathione peroxidase and catalase. However the peroxiredoxins discovered in the past decade form a large family of highly conserved thioredoxin-dependent peroxide reductases, which are present in most tissues. We investigated whether peroxiredoxins I and II are present in pancreatic beta cells and if they are inducible by oxidative and nitrosative stress.

Methods. To detect these enzymes in insulin-producing beta cells we used semiquantitative RT-PCR, western blots and immunohistochemistry. The expression
\end{abstract}

of peroxiredoxins I and II was analysed after treatment with cytokines, hydrogen peroxide, alloxan or streptozotocin in the rat insulinoma cells INS-1 using RT-PCR and western blots.

Results. We show that peroxiredoxins I and II are present in the cytoplasm of pancreatic islet cells as well as in insulinoma cell lines $\beta$ TC6-F7 and INS-1. Peroxiredoxins I and II were up-regulated by all stress agents used.

Conclusion/interpretation. Beta cells, undersupplied with well characterized antioxidant enzymes, possess an additional antioxidant system which is inducible by oxidative as well as nitrosative stress. [Diabetologia (2002) 45:867-876]

Keywords Peroxiredoxin, stress, pancreatic beta cells, diabetes, cytokines, alloxan, streptozotocin.
During the pathogenesis of Type I (insulin-dependent) diabetes mellitus, oxidative and nitrosative stress contribute to the destruction of insulin-producing beta

Received: 3 December 2001 / Revised: 5 February 2002 Published online: 15 May 2002

(C) Springer-Verlag 2002

A. Bast and G. Wolf contributed equally to this work.

Corresponding author: Dr. R. Walther, Institut für Medizin Biochemie und Molekularbiologie der Ernst-Moritz-Arndt Universität Greifswald, Klinikum/Sauerbruchstraße, 17487 Greifswald, Germany, e-mail: rwalther@mail.uni-greifswald.de Abbreviations: Prx, Peroxiredoxin; SOD, superoxide dismutase; GPX, glutathione peroxidase; CAT, catalase; Tx, thioredoxin; TxR, thioredoxin reductase; IL-1 $\beta$, interleukin-1 $\beta$; GAPDH, glyceraldehyde-3-phosphate dehydrogenase cells $[1,2,3,4,5]$. Beta cells are very sensitive to cytotoxic stress because they express very little of the well known antioxidant enzymes like superoxide dismutase (SOD), glutathione peroxidase (GPX) and catalase (CAT) $[6,7,8]$. Moreover these antioxidant enzymes are able to reduce oxygen radicals but they can not protect against nitrosative stress [9].

Peroxiredoxins (Prxs) represent a recently discovered family of antioxidant proteins without any sequence homology to the antioxidant enzymes mentioned above. Six members of the Prx family have been identified to date (Prx I-VI). They are detected in a wide variety of organisms ranging from prokaryotes to mammals and are expressed in most cell types, though different Prx enzymes have distinct intracellular distributions $[10,11,12,13,14,15,16]$. Peroxiredoxins act as homodimers or heterodimers $[17,18$, 
19] and catalyse reduction of both hydrogen peroxide and alkyl peroxides to water or to the corresponding alcohol using thioredoxin (Tx) as their physiological hydrogen donor [20,21, 22, 23, 24]. Additionally it has been shown that the bacterial peroxiredoxin AhpC (alkylhydroperoxide reductase subunit $\mathrm{C}$ ) is able to protect against nitrogen radicals [25]. Prx enzymes have been identified in association with various cellular functions apparently unrelated to peroxidase activity. Several lines of evidence support the concept that peroxiredoxins can influence cell proliferation and differentiation, immunological defence, receptor signalling and apoptosis [10, 23, 26, 27, 28, 29]. This is reflected by the numerous synonyms used. Thus Prx I is further known as MSP23 (mouse macrophage stress protein $\mathrm{M}_{\mathrm{r}} 23 \mathrm{~K}$ ) [30], OSF3 (mouse osteoblast specific factor 3) [31], HBP23 (heme-binding protein $\mathrm{M}_{\mathrm{r}}$ $23 \mathrm{~K}$ ) [32], PAG (proliferation-associated gene) [10] and NKEF-A (human natural killer cell-enhancing factor-A) [33]. Prx I is a physiological inhibitor of cAbl kinase activity [34]. It is induced by oxidative stress in peritoneal macrophages exposed to heavy metals, oxidized low-density lipoproteins or heme [30, $35,36,37]$.

Prx II was originally isolated from yeast. It is also named thiol-specific antioxidant (TSA) [38, 39], protector protein (PRP) $[11,26]$, human natural killer cell-enhancing factor-B (NKEF-B) [33, 41, 40], calpromotin [19, 42, 43] and torin [44]. Prx II is important in erythroid cell differentiation $[11,26]$ and protects red blood cell membranes from peroxidation [20, 45]. It also regulates signal transduction pathways that directly relate to apoptotic cell death $[23,27,28,29$, 46]. Prx II is thought to protect neuronal cells against destruction by hypoxia and ischaemia $[11,47]$ and tumour cells against X-ray treatment and chemotherapy [48].

We investigated the occurrence of peroxiredoxins I and II in pancreatic beta cells and determined whether expression of these enzymes is up-regulated by cytokines, hydrogen peroxide, alloxan and streptozotocin.

\section{Material and Methods}

Materials. Female BalbC mice (6-8 weeks) were purchased from the Department of Pathophysiology and the Department of Zoology, NMRI mice were from the Department of Neurology, Greifswald University. We confirm that the 'Principles of laboratory animal care' (NIH publication no. 85-23, revised 1985) were followed as well as any specific national laws applicable in Germany. Collagenase type IV and antibody against glucagon were obtained from Sigma (Deisenhofen, Germany). Taq polymerase was from Amersham Pharmacia Biotech (Freiburg, Germany). Cytokines and antibody against insulin were obtained from Roche Diagnostics (Mannheim, Germany). Rotiblock was from Carl Roth (Karlsruhe, Germany). Streptozotocin was obtained from Calbiochem Novabiochem (Schwalbach, Germany) and alloxan was from ICN (Eschwege, Germany). Preparation of antiserum against Prx I and II and preimmunsera has been described in [49]. The secondary antibodies anti mouse-Cy2 and anti rabbit-Cy3 were obtained from Dianova (Hamburg, Germany). All other chemicals were from commercially available sources.

Cell culture. Mouse insulinoma cells $\beta$ TC6-F7 (passages 15-20) were propagated in DMEM medium containing $5.5 \mathrm{mmol} / \mathrm{l}$ glucose, supplemented with $10 \%$ heat-inactivated FCS, $100 \mathrm{U} / \mathrm{ml}$ penicillin and $100 \mu \mathrm{g} / \mathrm{ml}$ streptomycin. Rat insulinoma cells INS-1 (passages 13-20) were propagated in RPMI-1640 medium containing $11 \mathrm{mmol} / \mathrm{l}$ glucose, supplemented with $10 \%$ heat-inactivated FCS, $100 \mathrm{U} / \mathrm{ml}$ penicillin, $100 \mu \mathrm{g} / \mathrm{ml}$ streptomycin, $10 \mathrm{mmol} / \mathrm{l}$ HEPES-buffer, $2 \mathrm{mmol} / \mathrm{l}$ L-glutamine, $1 \mathrm{mmol} / \mathrm{l}$ sodium pyruvate, $50 \mu \mathrm{mol} / \mathrm{l} \beta$-mercaptoethanol. All cells were cultured at $37^{\circ} \mathrm{C}$ in a humidified atmosphere containing $95 \%$ air and $5 \% \mathrm{CO}_{2}$.

Isolation of pancreatic islets. Islets were isolated from female NMRI mice ( 8 weeks old). Pancreas were dissected, rinsed with ice-cold HBSS solution, minced and digested with $1 \mathrm{mg} / \mathrm{ml}$ Typ IV collagenase for $12 \mathrm{~min}$ at $30^{\circ} \mathrm{C}$. Digestion was stopped by adding ice-cold HBSS solution containing 5\% FCS. Pancreatic islets were selected under a stereomicroscope, collected into cell culture dishes and cultured under the same conditions as INS-1 cells.

For western blot analyses islets were collected by centrifugation, resuspended in $500 \mu \mathrm{l}$ lysis buffer $(480 \mathrm{mg} / \mathrm{ml}$ urea, $152 \mathrm{mg} / \mathrm{ml}$ thiourea, $40 \mathrm{mg} / \mathrm{ml}$ CHAPS, $20 \mathrm{mg} / \mathrm{ml}$ DTT and $9.6 \mathrm{mg} / \mathrm{ml}$ Tris) and sonicated. The lysate was ultracentrifugated for $1 \mathrm{~h}$ at $8^{\circ} \mathrm{C}$ and $103000 \times \mathrm{g}$.

Exposure of INS-1 cells and pancreatic islets to stress agents. Monolayers of confluent INS-1 cells or isolated pancreatic islets were incubated for the indicated periods with or without stress agents in culture medium. After exposure to alloxan or streptozotocin, cells were incubated for an additional $8 \mathrm{~h}$ in medium without stress agents. INS-1 cells and pancreatic islets were harvested for RNA or protein isolation. Preparation of cytosolic and nuclear extracts for western blot analysis were done as described [50].

Semiquantitative RT-PCR. RT-PCR quantitated Prx I and Prx II mRNA in oxidant-treated cells. Total INS-1 RNA was isolated from $60 \mathrm{~mm}$ dishes using a commercial kit (Qiagen). cDNA was prepared by reverse transcription of $2 \mu \mathrm{g}$ of total RNA using 0.5 $\mu \mathrm{g}$ BamTT-primer (3'-CGC GGA TCC TTT TTT TTT TTT TTT TTT-5') and superscript II reverse transcriptase. Prx I and Prx II were amplified with Taq DNA polymerase in a DNA thermal cycler (Eppendorf) using the following gene-specific primer pairs: Prx I: 5'-GTG GAT TCT CAC TTC TGT CAT CT-3' and 5'-GGC TTA TCT GGA ATC ACA CCA CG-3' with an expected product of 470 bp; Prx II: 5'GAG GGA AGT ACG TGG TCC TCT-3' and 5'-GGT AGG TCA TTG ACT GTG ATC TG-3' with an expected product of $339 \mathrm{bp}$. The conditions for each cycle were $30 \mathrm{~s}$ at $94^{\circ} \mathrm{C}, 40 \mathrm{~s}$ at $63^{\circ} \mathrm{C}$ or $57^{\circ} \mathrm{C}$ and $60 \mathrm{~s}$ at $72^{\circ} \mathrm{C}(25$ cycles $)$. In parallel, RTPCR was carried out with primers specific for GAPDH $\left(5^{\prime}-\right.$ GTC GTG GAG TCT ACT GGC GTC TTC-3' and 5'-GTT GTC ATT GAG AGC AAT GCC AGC-3' with an expected product of $635 \mathrm{bp}$ ) as a control for equal amounts of RNA used in the RT-reaction.

Western blot. Proteins $(20 \mu \mathrm{g})$ were separated by $12.5 \%$ SDSPAGE and electroblotted onto nitrocellulose membranes using a semi-dry blotter. The blot was blocked with "Rotiblock" for $1 \mathrm{~h}$ at room temperature and subsequently incubated in a 1:2000 dilution of a polyclonal rabbit anti-Prx I or anti-Prx II 
antiserum. After washing the blot with PBS-Tween $0.05 \%$, an alkaline phosphatase-conjugated goat anti-(rabbit) IgG $(1: 10000)$ was used as a secondary antibody. Bound antibody was detected with BCIP and NBT as substrate.

Cryostat slices. Pancreas from BalbC mice was incubated for 4 to $6 \mathrm{~h}$ at $4^{\circ} \mathrm{C}$ in paraformaldehyde ( $4 \%$ in $5 \times$ phosphate buffer) and then 12 to $16 \mathrm{~h}$ in sucrose (5\% in $5 \times$ phosphate buffer). After shock-freezing in isopentane the tissue was embedded in Tissue Tec and stored at $-80^{\circ} \mathrm{C}$. Cryostat sections of 8 to $10 \mu \mathrm{m}$ were used for immunohistochemistry.

Immunohistochemistry. Slices were successively incubated for $5 \mathrm{~min}$ in ice-cold methanol, acetone and IF-buffer $(0.2 \%$ BSA, $0.05 \%$ saponine, $0.1 \%$ sodium azide in PBS pH 7.4) followed by an overnight incubation at $4^{\circ} \mathrm{C}$ with polyclonal rabbit antiPrx I or anti-Prx II antiserum and monoclonal mouse anti-glucagon or anti-insulin antibody diluted 600-fold in IF-buffer. After washing with IF-buffer, the immunoreacted primary antibodies were visualised with red fluorescent $\mathrm{Cy} 3$-conjugated goat anti-rabbit $\operatorname{IgG}(1: 400)$ and green fluorescent Cy2-conjugated goat anti-mouse $\operatorname{IgG}(1: 400)$, by incubation for $2 \mathrm{~h}$ at room temperature in the dark. After washing with IF-buffer again, slices were covered with glycerol gelatin and observed by fluorescent microscopy (400x magnification) with an IX-70 microscope (Olympus). Control staining with preimmune sera gave no immunoreactive signals.

\section{Results}

Detection of peroxiredoxins I and II in pancreatic beta cells. To establish the expression of Prx I and Prx II in pancreatic beta cells, insulinoma cells were cultured for $24 \mathrm{~h}$. The amount of mRNA of both Prx enzymes was examined by RT-PCR using total RNA from mouse $\beta$ TC6-F7 cells (data not shown) and rat INS-1 cells (Fig. 1A). We detected $\operatorname{Prx} I$ as well as $\operatorname{Prx} I I$ mRNA in both insulinoma cell lines. Each primer set yielded a single PCR product of the size predicted (Fig. 1A).

To determine the subcellular distribution of both peroxiredoxins, nuclear and cytosolic fractions of INS-1 cells were subjected to immunoblot analysis using polyclonal antisera. Prx I and II were detected, at different expressions, almost exclusively in the cytosolic fraction of INS-1 cells. The western blot showed a major band at $\mathrm{M}_{\mathrm{r}} 23 \mathrm{~K}$, representing the monomer, and a fainter band at $\mathrm{M}_{\mathrm{r}} 46 \mathrm{~K}$, representing the dimer. There were only weak multiple protein bands in the nuclear fraction (Fig. 1B).

Furthermore we stained cryostat slices of pancreas from BalbC mice to analyse the presence of peroxiredoxins in endocrine and exocrine tissue. Figure 2 shows the green fluorescent, centrally situated insulinproducing beta cells $(\mathrm{a}, \mathrm{g})$ and the surrounding glucagon-producing alpha cells $(\mathrm{d}, \mathrm{j})$. The red fluorescent signals represent Prx I (b, e) or Prx II (h, k). Immunostaining signals were not visible when the corresponding preimmune sera were used. The colocalisation of Prx I (c, f) or Prx II $(i, 1)$ with insulin or glucagon results in yellow immunostaining. Peroxiredoxins are
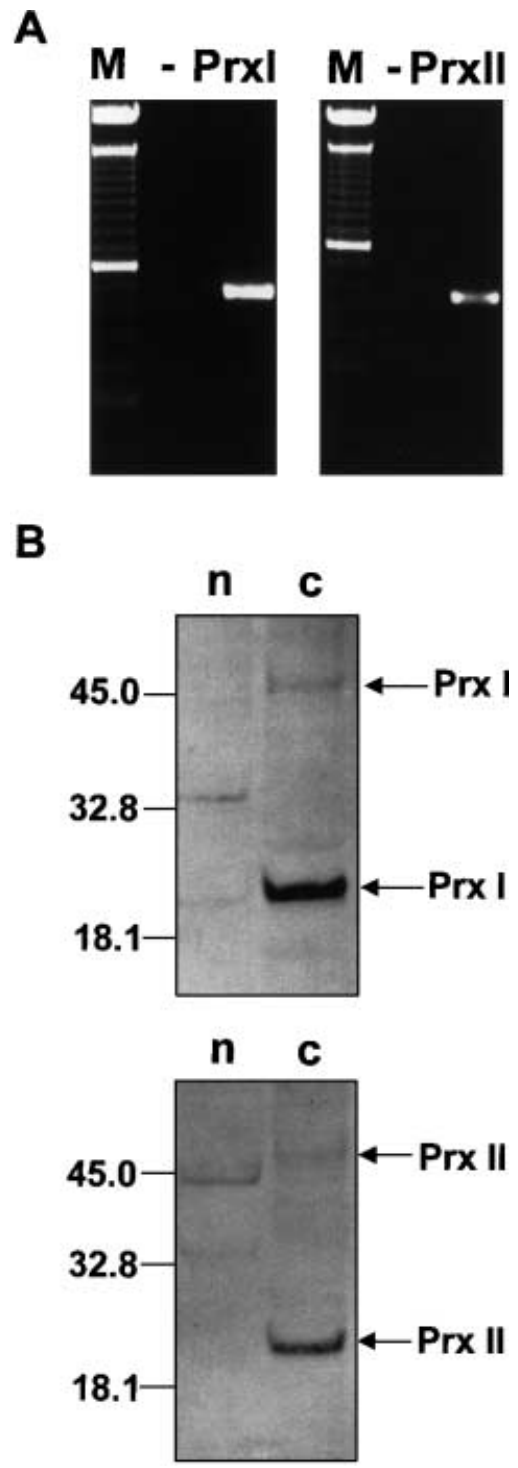

Fig. 1A, B. Expression of Prx I and Prx II in pancreatic beta cells. A RT-PCR. Total RNA from INS-1 cells was analysed. A negative control (-) without RNA was carried out. The major bands of the marker $(\mathrm{M})$ represent DNA size of $0.6 ; 1.5$ and $2 \mathrm{~kb}$, respectively. B Western blot analysis. $20 \mu \mathrm{g}$ nuclear (n) or cytosolic (c) proteins were separated on SDS-12.5\% polyacrylamide gels. Molecular size standards (in K) are indicated on the left

predominantly expressed in pancreatic islets, only low signals are observed in exocrine cells of the pancreas. The micrographs confirmed cytosolic localisation of both peroxiredoxins shown (Fig. 1B).

Up-regulation of Prx I and II expression by cytokines. To mimic the conditions during autoimmune destruction in the pancreas, insulinoma cells INS-1 were exposed to IL-1 $\beta$, IFN- $\gamma$ and TNF- $\alpha$ for $48 \mathrm{~h}$. The effects on mRNA and protein level were examined by semiquantitative RT-PCR and western blot analysis. Treating with IL-1 $\beta(50 \mathrm{U} / \mathrm{ml})$ increased the $\operatorname{Prx} I$ mRNA amount. The combination of IL1 $\beta$ 

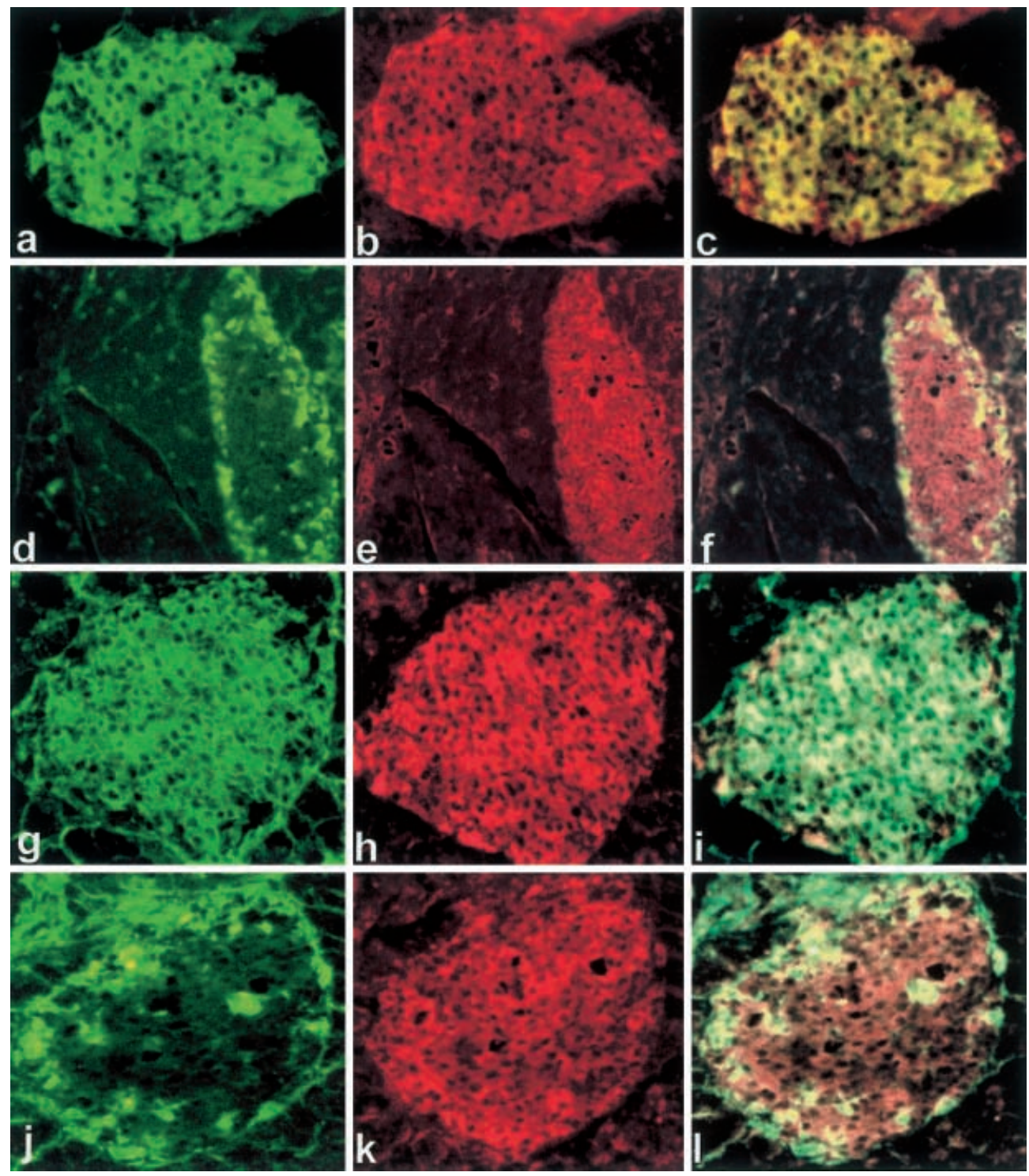

Fig. 2a-l. Expression of Prx I and Prx II in pancreatic beta cells. Immunohistochemistry. Cryostat slices of BalbC mouse pancreas were stained with antisera against Prx I (b, c, e, f) or Prx II (h, i, k, l) in parallel with antibodies against insulin (a, c, $\mathrm{g}$, i) or glucagon $(\mathrm{d}, \mathrm{f}, \mathrm{j}, \mathrm{l})$. Immunopositive staining is indicated by green fluorescence for insulin or glucagon and by red fluorescence for Prx I or Prx II. Colocalisation results in a yellow fluorescence. (magnification $\times 400$ )

$(50 \mathrm{U} / \mathrm{ml}), \mathrm{IFN}-\gamma(100 \mathrm{U} / \mathrm{ml})$ and TNF- $\alpha(10 \mathrm{ng} / \mathrm{ml})$ had an additive effect on the content of Prx I mRNA. However, mRNA amount of the Prx II gene was not altered (Fig. 3A). The western blot (Fig. 3B) showed a low basal expression of Prx I and II markedly enhanced by cytokines. The amount of the monomers as well as the dimers was increased. These results were confirmed with pancreatic islets isolated from NMRI mice and treated with cytokines (Fig. 3C).

Up-regulation of Prx I and II expression by hydrogen peroxide. To analyse the effect of oxidative stress,
INS-1 cells were treated for $2 \mathrm{~h}$ with hydrogen peroxide at a concentration of $150 \mu \mathrm{mol} / \mathrm{l}$ or $450 \mu \mathrm{mol} / \mathrm{l}$. Semiquantitative RT-PCR (Fig. 4A) showed a dosedependent up-regulation of Prx I mRNA. The amount of Prx II mRNA however, was not changed. Protein contents were examined by immunoblotting. The synthesis of the monomers of Prx I as well as Prx II was increased (Fig. 4B).

Up-regulation of Prx I and II expression by allox$a n$. The beta cell toxin alloxan is used to generate animal models of Type I diabetes mellitus. The substance is able to destroy insulin-producing beta cells by generating oxygen radicals [51]. We investigated the effect of alloxan on Prxs expression in INS-1 cells using semiquantitative RT-PCR and western blot analysis. After exposing cells to different concentrations of alloxan for $30 \mathrm{~min}$ followed by an 8-h recovery period, the amount of $\operatorname{Prx} I$ mRNA, but not $\operatorname{Pr} x$ II mRNA, increased (Fig. 5A). The immunoblot (Fig. 5B) shows a dose-dependent enhancement of both, Prx I and Prx II, 
A

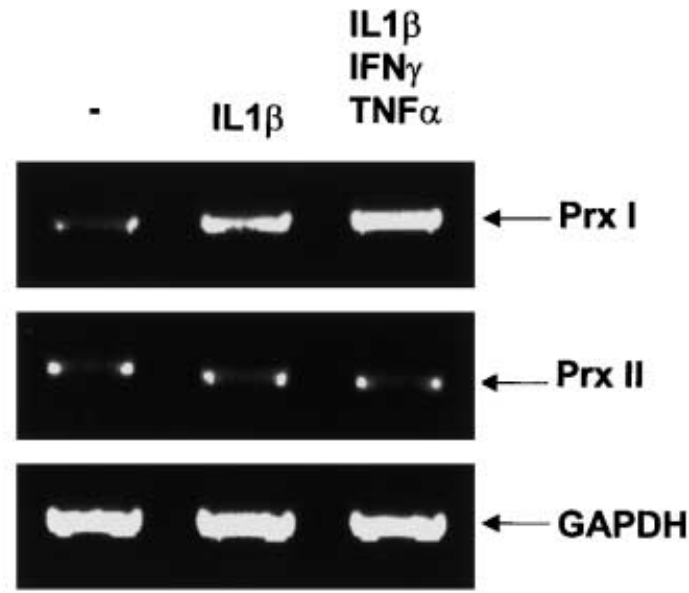

B
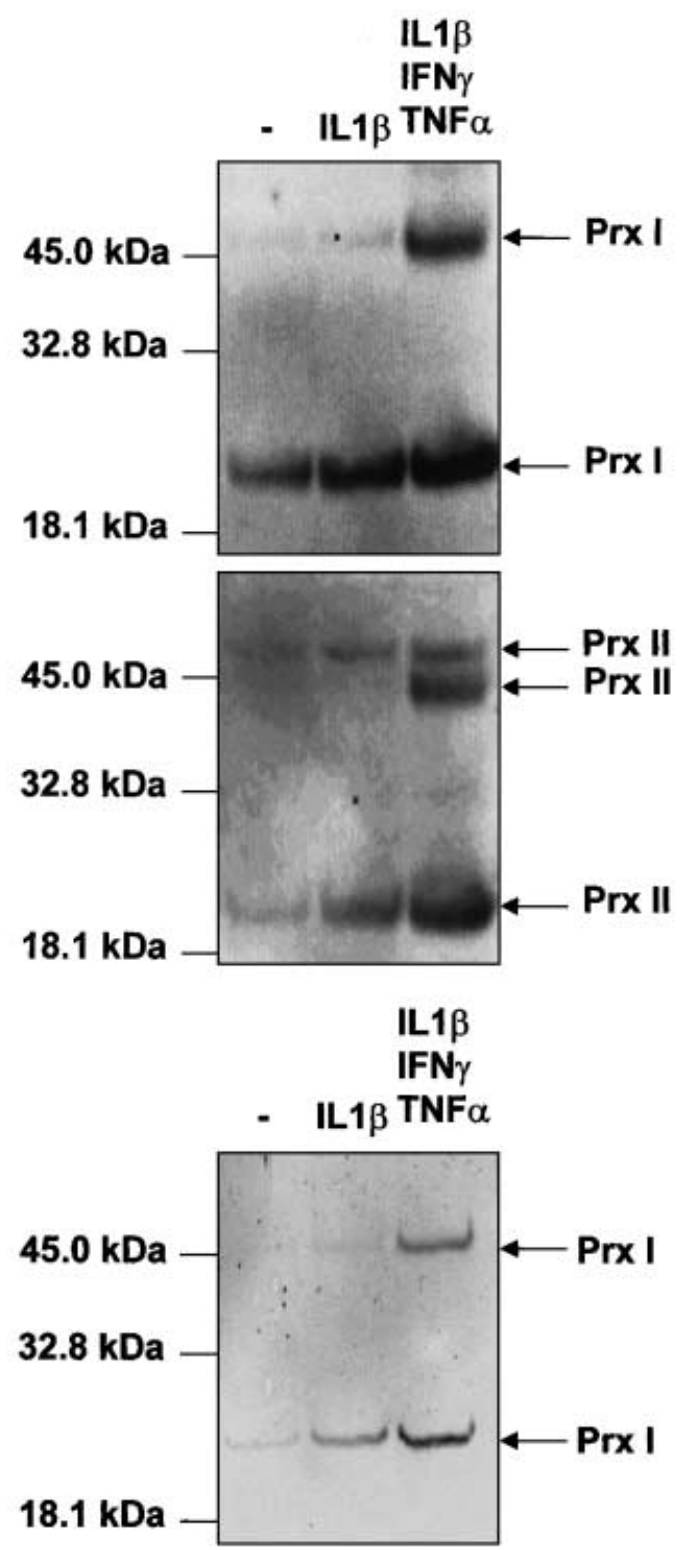

Fig. 3A-C. Up-regulation of Prx I and Prx II expression in INS- 1 cells and islets by cytokines. INS- 1 cells and isolated islets were exposed for $48 \mathrm{~h}$ to $50 \mathrm{U} / \mathrm{ml} \mathrm{IL}-1 \beta$ or a combination

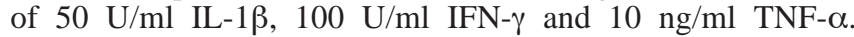
A RT-PCR. Total RNA from INS-1 cells was analysed. As
A
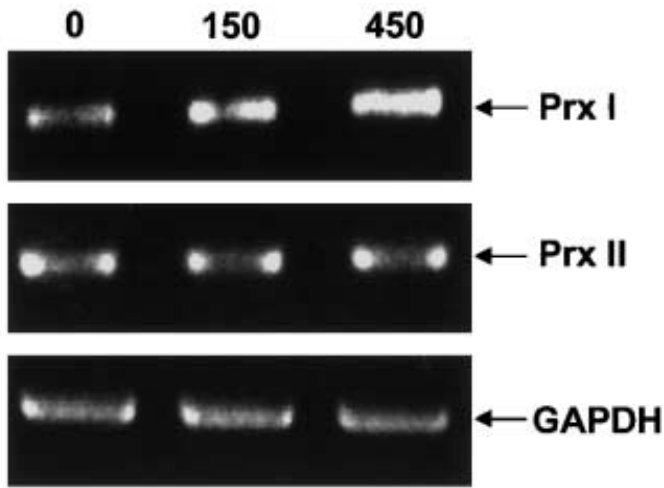

B
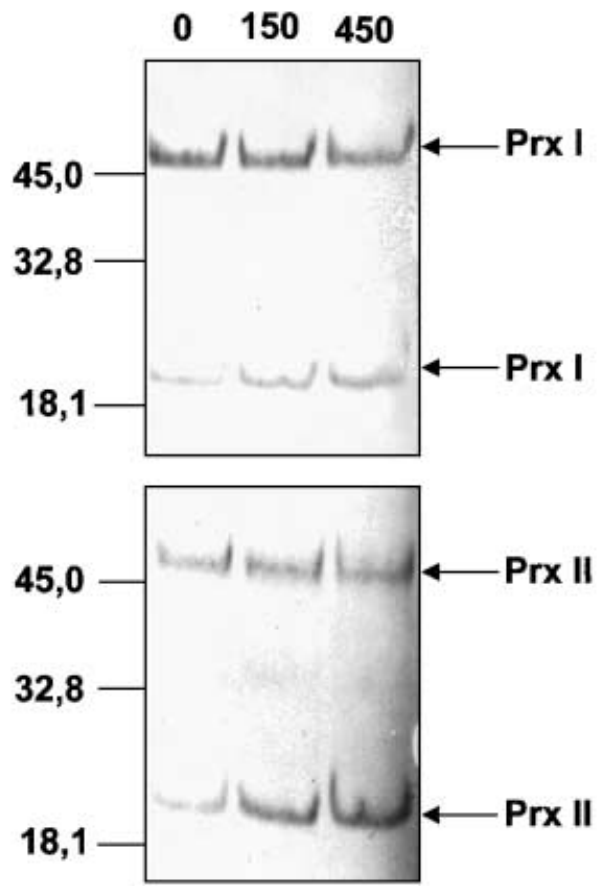

Fig. 4A, B. Up-regulation of Prx I and Prx II expression in INS-1 cells by hydrogen peroxide. A RT-PCR. RNA was isolated from INS-1 cells treated for $2 \mathrm{~h}$ in the absence $(0)$ or the presence of $150 \mu \mathrm{M}$ or $450 \mu \mathrm{M}$ of hydrogen peroxide. As control, cDNA was amplified with GAPDH-specific primers. B Western blot analysis. $20 \mu \mathrm{g}$ cytoplasmic proteins of INS-1 cells exposed for $2 \mathrm{~h}$ to 0,150 or $450 \mu \mathrm{mol} / 1$ hydrogen peroxide were separated by SDS-PAGE (12.5\%). Molecular size standards are indicated on the left in $\mathrm{K}$

protein amount. In contrast to hydrogen peroxide, treatment with alloxan led to an increased synthesis of only the dimers.

Up-regulation of Prx I and II expression by streptozotocin. In contrast to alloxan, the diabetogenic substance streptozotocin induces nitrosative stress in pan-

control, cDNA was amplified with GAPDH-specific primers, confirming similar loading in all lanes. Western blot analysis. $20 \mu \mathrm{g}$ cytosolic proteins from INS-1 cells (B) and isolated islets (C) were separated on SDS-12.5\% polyacrylamide gels. Molecular size standards are indicated on the left in $\mathrm{K}$ 
A
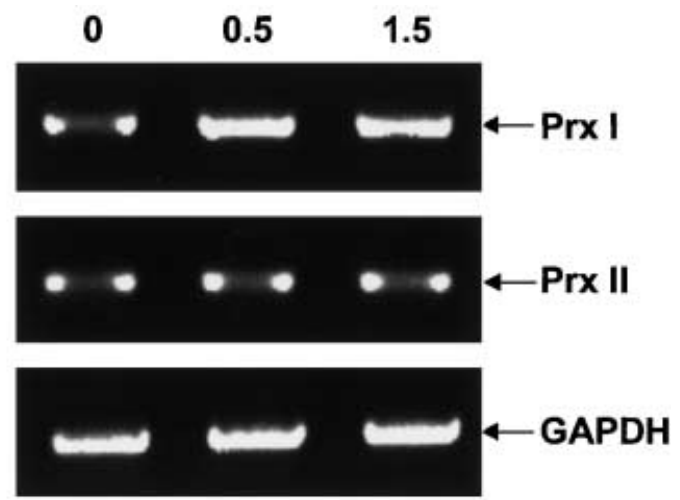

B
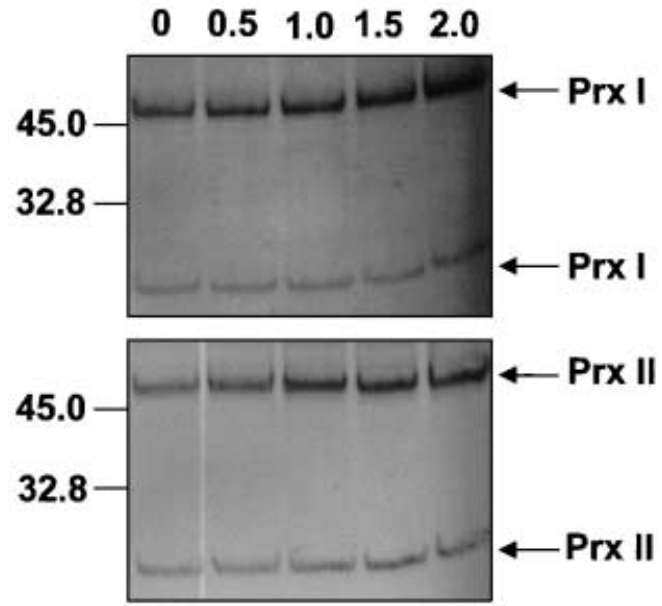

Fig. 5A, B. Up-regulation of Prx I and II expression by alloxan. After overnight culture cells were incubated for $30 \mathrm{~min}$ with alloxan for the indicated concentrations ( $\mathrm{mmol} / \mathrm{l})$, followed by an $8 \mathrm{~h}$ recovery period. A RT-PCR. Total RNA was analysed. As control, cDNA was amplified with GAPDH-specific primers, confirming similar loading in all lanes. B Western blot analysis. $20 \mu \mathrm{g}$ cytosolic proteins were separated on SDS- $12.5 \%$ polyacrylamide gels. Molecular size standards are indicated on the left in $\mathrm{K}$

creatic beta cells by inducing overproduction of free radical nitric oxide [52]. INS-1 cells were cultured for $30 \mathrm{~min}$ in the absence or the presence of increasing concentrations of streptozotocin. RNA and cytosolic proteins were isolated for semiquantitative RT-PCR and western blot analysis. The mRNA contents of Prx $I$ were up-regulated. However, mRNA amount of the Prx II gene was not altered (Fig. 6A). Exposure of INS-1 cells to streptozotocin increased Prx I and Prx II protein content dose-dependently (Fig. 6B).

\section{Discussion}

In aerobic organisms, many metabolic processes generate reactive oxygen species, which cause cellular damage by oxidising lipids, proteins, and nucleic acids. These processes have been implicated in apoptosis, ageing and in the aetiology of various diseases, in-
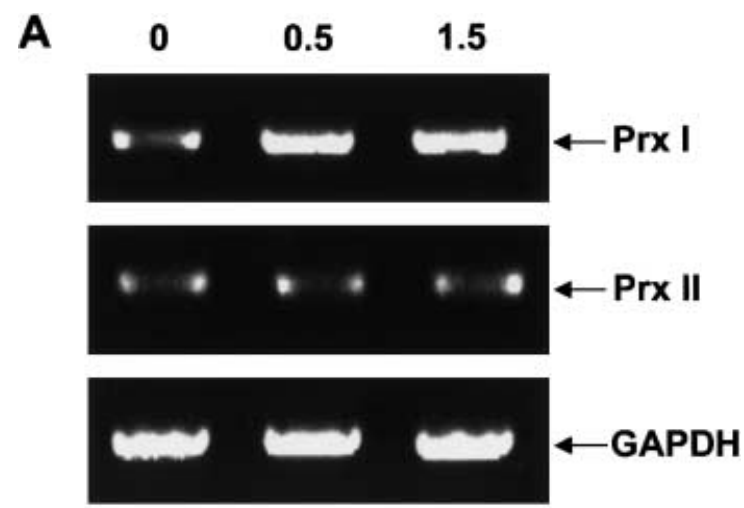

B $\begin{array}{llllll}0 & 0.5 & 1.0 & 1.5 & 2.0\end{array}$
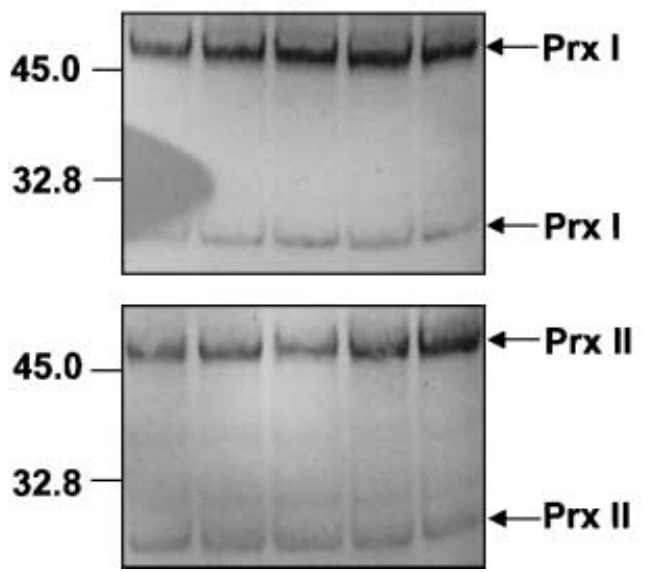

Fig. 6A, B. Up-regulation of Prx I and Prx II expression by streptozotocin. A RT-PCR. Total RNA was isolated from INS1 cells exposed to $0-1.5 \mathrm{mmol} / 1$ streptozotocin for $30 \mathrm{~min}$. As control, cDNA was amplified with GAPDH-specific primers. B Western blot analysis. $20 \mu \mathrm{g}$ cytosolic proteins were separated on SDS- $12.5 \%$ polyacrylamide gels. Molecular size standards are indicated on the left in $\mathrm{K}$

cluding diabetes. As protection against these cytotoxic oxygen species, all aerobic organisms have evolved a number of antioxidant proteins that can scavenge reactive oxygen intermediates as well as repair or remove the damaged cellular components.

Peroxiredoxins, a large antioxidant gene family, have a wide tissue distribution but the highest expression of Prx I and Prx II occur in bone marrow, liver, testis, ovary and heart, followed by spleen and brain $[13,15]$. Using immunohistochemical staining of mouse pancreas we show that Prx I and Prx II expression is mainly localized to pancreatic islets, with almost no signals in exocrine pancreas. Islets represent only 2 to $3 \%$ of the pancreatic tissue. This could be the reason why Prx I as well as Prx II have not been detected in the total pancreas by northern blot analysis [15]. A similar expression pattern within the pancreas was found for Prx VI, but in contrast to our findings for Prx I and Prx II immunohistochemical analyses 
showed an extensive staining of nuclei in islet cells [53]. Using semiquantitative RT-PCR and western blot analyses we were able to detect Prx I and Prx II mRNA and protein of both peroxiredoxins in rat insulinoma cells INS1 and mouse insulinoma cells $\beta$ TC6F7.

Peroxiredoxins are in different subcellular compartments. While Prx III is localized to mitochondria [12, 22, 54, 55], Prx I and Prx II are found in the cytoplasm $[15,23,32,43]$. Furthermore Prx I is thought to be translocated into the nucleus by association with other proteins such as tyrosine kinase $\mathrm{c}-\mathrm{Abl}$, though given its small size it could enter passively [34]. Our findings support that Prx I and Prx II are localized to the cytoplasm (Fig. 1B, Fig. 2).

With monomer masses of about $\mathrm{M}_{\mathrm{r}} 23 \mathrm{~K}$ peroxiredoxins are small peroxide reductases. Peroxiredoxins form both homodimers and heterodimers, which are linked through head-to-tail disulfide bonds between the conserved amino-terminal and carboxyterminal cysteines. Although both cysteines are required to form dimers, only the amino-terminal cysteine is absolutely required for the antioxidation function. By coupling with the redox cycle of thioredoxin, peroxiredoxins can transfer the reducing equivalents to scavenge reactive oxygen species. In western blot analyses we found both monomers and dimers. However, formation of heterodimers was difficult to distinguish from homodimers based on electrophoretic migration in polyacrylamide gel electrophoresis, because peroxiredoxins have very similar molecular sizes. Furthermore we detected an additional dimer signal of Prx II after exposure of INS-1 cells to a combination of three cytokines, probably caused by the interaction with cytoplasmic proteins. Several lines of evidence support the view that cyclophilins with molecular masses around $20 \mathrm{~K}$ are able to bind to peroxiredoxins and could enhance their antioxidant activity $[56,57]$.

Up-regulation of peroxidoredoxins in pancreatic beta cells by cellular stress. Although several functions and activities of peroxiredoxins have already been described in a variety of cells and tissues, the role of these peroxide reductases in the pancreas, especially in islet cells, is not known. We investigated Prxs expression on the level of mRNA and protein in mouse pancreatic islets and rat insulin-producing cells INS-1 after exposure to stress.

Our study shows that expression of peroxiredoxins I and II is enhanced in cultured INS-1 cells exposed to various stress agents, including the diabetogenic substances alloxan and streptozotocin. Furthermore we indicate that Prx I and II are differentially regulated at the transcriptional and translational level during stress conditions. Semiquantitative RT-PCR showed up-regulation of Prx I but not Prx II mRNA. In contrast, western blot analyses showed enhanced protein contents of both Prx I and Prx II (Figs. 3, 4, 5, 6). The dif- ferent regulation of peroxiredoxins on mRNA and protein level is thought to be dependent on the stress agent and cell type [29, 58].

Cytokines like IL-1 $\beta$, IFN- $\gamma$ and TNF- $\alpha$ have been implicated in the pathogenesis of Type I diabetes and could be a major source of free radical insult in pancreatic islet cells $[5,59,60]$. An effect of cytokines (IFN- $\gamma$ ) on expression of peroxiredoxins has been shown only in rat Kupffer cells [37]. We show that cytokines up-regulate Prxs in INS-1 cells as well as in isolated pancreatic islets. The highest induction was observed with a combination of three cytokines. The cytokine-induced increase of peroxiredoxin expression could correlate with the control of reactive oxygen radical and nitrogen oxide, which are generated by IL1- $\beta$, IFN- $\gamma$ and TNF- $\alpha$ in beta cells.

We found that treatment of INS-1 cells with hydrogen peroxide did have an effect on the accumulation of Prx I mRNA and protein, but that the Prx II protein content was more dramatically increased than that of Prx I. An up-regulation of peroxiredoxins in response to hydrogen peroxide has been observed in the mouse macrophage cell line RAW [58], and in mouse peritoneal macrophages [30], but not in endothelial cell lines ECV304 [61] and HUVEC [62]. This strongly suggests that induction of peroxiredoxins by stress inducing agents is dependent on cell type.

Alloxan and streptozotocin cause a selective destruction of insulin-producing cells by overproduction of reactive oxygen and nitrogen intermediates [51, 52, 63]. Up to now there are no data on their influence on peroxiredoxin expression. We show the induction of both Prx I and Prx II expression in INS-1 cells by both substances. Up-regulation of peroxiredoxins by streptozotocin was more effective than by alloxan. An influence of substances, which directly release nitric oxide on peroxiredoxin expression has already been reported. A dose-dependent increase of peroxiredoxin I mRNA amount in rat Kupffer cells were found after exposure to both the nitric oxide (NO)-donor SNAP and the peroxynitrite donor SIN-1 [37].

Since there are only low concentrations of SOD, CAT and GPX in pancreatic beta cells $[6,7,8,9]$, peroxiredoxins could play an important role as an antioxidant system particularly because, in contrast to these well characterized antioxidant enzymes [8, 9, 64], gene expression of peroxiredoxins is adjustable by oxidative and nitrosative stress agents. The induction of cellular stress by high glucose, high oxygen, and heat shock treatment has been shown not to affect CAT, SOD or GPX expression in rat pancreatic islets or in RINm5F cells [8]. Insulin-producing cells could not adapt the low antioxidant basal enzyme activity to typical situations of cellular stress by an up-regulation of mRNA and protein content [8].

In addition, inactivation of glutathione peroxidase by nitric oxide has been observed [65]. The bacterial peroxiredoxin AhpC (alkylhydroperoxide reductase 
subunit C) has been shown to protect cells against reactive nitrogen intermediates, such as nitric oxide [25]. There is evidence that detoxification of peroxynitrite by peroxiredoxin $\mathrm{AhpC}$ is seven times faster than by glutathione peroxidase. The reduction of peroxynitrite was shown to be fast enough to forestall the oxidation of bystander molecules such as DNA [66]. Peroxiredoxins are at least twice as effective as catalase in protecting glutamine synthetase from inactivation $[33,41]$. The overexpression of both Prx I and Prx II protected fibroblasts and lymphoma cells against oxidant-induced apoptosis [27, 67]. Furthermore, targeted overexpression of thioredoxin, the physiological reducing agent of peroxiredoxins, in pancreatic beta cells of NOD mice remarkably reduced the incidence of diabetes in untreated and in streptozotocin-treated animals. Thus a thioredoxindependent antioxidant system is able to prevent beta cell destruction [68].

Our data suggest that the induction of Prx expression is part of the cellular response to oxidative and nitrosative stress as well. For this reason peroxiredoxins are important antioxidant proteins providing protection against toxic agents. However, the mechanisms that control the content of intracellular Prxs are still not known. Therefore, a better understanding of both function and regulation of peroxiredoxins could be of clinical interest and important for the prevention of diabetes.

Acknowledgements. The authors would like to thank A. PopaWagner and H. Schmoll for their support in the preparation of cryostat slices and B. Jack for critically reading the manuscript. This work was supported by the foundation "Das zuckerkranke Kind" of Deutsche Diabetes Gesellschaft.

\section{References}

1. Eizirik DL, Flodström M, Karlsen AE, Welsh N (1996) The harmony of the spheres: inducible nitric oxide synthase and related genes in pancreatic beta cells. Diabetologia 39:875-890

2. Suarez-Pinzon WL, Szabo C, Rabinovitch A (1997) Development of autoimmune diabetes in NOD mice is associated with the formation of peroxynitrite in pancreatic islet betacells. Diabetes 46:907-911

3. Corbett JA, McDaniel ML (1992) Does nitric oxide mediate autoimmune destruction of $\beta$-cells? Diabetes 41:897903

4. Corbett JA, Wang JL, Hughes JH et al. (1992) Nitric oxide and cyclic GMP formation induced by interleukin 1 beta in islets of Langerhans. Evidence for an effector role of nitric oxide in islet dysfunction. Biochem J 287:229-235

5. Delaney CA, Paviovic D, Hoorens A, Pipeleers DG, Eizirik DL (1997) Cytokines induce deoxyribonucleic acid strand breaks and apoptosis in human pancreatic islet cells. Endocrinology 138:2610-2614

6. Grankvist K, Marklund SL, Taljedal IB (1981) CuZn-superoxide dismutase, Mn-superoxide dismutase, catalase and glutathione peroxidase in pancreatic islets and other tissues in the mouse. Biochem J 199:393-398
7. Lenzen S, Drinkgern J, Tiedge M (1996) Low antioxidant enzyme gene expression in pancreatic islets compared with various other mouse tissues. Free Radic Biol Med 20: 463-466

8. Tiedge M, Lortz S, Drinkgern J, Lenzen S (1997) Relation between antioxidant enzyme gene expression and antioxidative defense status of insulin-producing cells. Diabetes 46:1733-1742

9. Tiedge M, Lortz S, Munday R, Lenzen S (1999) Protection against the co-operative toxicity of nitric oxide and oxygen free radicals by overexpression of antioxidant enzymes in bioengineered insulin-producing RINm5F cells. Diabetologia 42:849-855

10. Prosperi MT, Ferbus D, Karczinski I, Goubin G (1993) A human cDNA corresponding to a gene overexpressed during cell proliferation encodes a product sharing homology with amoebic and bacterial proteins. J Biol Chem 268: $11050-11056$

11. Ichimiya S, Davis JG, O'Rourke DM, Katsumata M, Greene MI (1997) Murine thioredoxin peroxidase delays neuronal apoptosis and is expressed in areas of the brain most susceptible to hypoxic and ischemic injury. DNA Cell Biology 16:311-321

12. Araki M, Nanri H, Ejima K et al. (1999) Antioxidant function of the mitochondrial protein SP-22 in the cardiovascular system. J Biol Chem 274:2271-2278

13. Matsumoto A, Okado A, Fujii T et al. (1999) Cloning of the peroxiredoxin gene family in rats and characterization of the fourth member. FEBS Lett 443:246-250

14. Chae HZ, Rhee SG (1994) A thiol-specific antioxidant and sequence homology to various proteins of unknown function. Biofactors 4:177-180

15. Chae HZ, Kim HJ, Kang SW, Rhee SG (1999) Characterization of three isoforms of mammalian peroxiredoxin that reduce peroxides in the presence of thioredoxin. Diabetes Res Clin Pract 45:101-112

16. Lyu MS, Rhee SG, Chae HZ et al. (1999) Genetic mapping of six mouse peroxiredoxin genes and fourteen peroxiredoxin related sequences. Mamm Genome 10:10171019

17. Chae HZ, Uhm TB, Rhee SG (1994) Dimerization of thiolspecific antioxidant and the essential role of cysteine 47. Proc Natl Acad Sci USA 91:7022-7026

18. Jin DY, Chae HZ, Rhee SG, Jeang KT (1997) Regulatory role for a novel human thioredoxin peroxidase in NF- $\mathrm{KB}$ activation. J Biol Chem 272:30952-30961

19. Kristensen P, Rasmussen DE, Kristensen BI (1999) Properties of thiol-specific anti-oxidant protein or calpromotin in solution. Biochem Biophys Res Commun 262:127-131

20. Lim YS, Cha MK, Kim HK et al. (1993) Removals of hydrogen peroxide and hydroxyl radical by thiol-specific antioxidant protein as a possible role in vivo. Biochem Biophys Res Commun 192:273-280

21. Netto LES, Chae HZ, Kang SW, Rhee SG, Stadtman ER (1996) Removal of hydrogen peroxide by thiol-specific antioxidant enzyme (TSA) is involved with its antioxidant properties. J Biol Chem 271:15315-15321

22. Watabe S, Hiroi T, Yamamoto Y et al. (1997) SP-22 is a thioredoxin-dependent peroxide reductase in mitochondria. Eur J Biochem 249:52-60

23. Kang SW, Chae HZ, Seo MS, Kim K, Baines IC, Rhee SG (1998) Mammalian peroxiredoxin isoforms can reduce hydrogen peroxide generated in response to growth factors and tumor necrosis factor- $\alpha$. J Biol Chem 273:62976302

24. Verdough L, Vignols F, Jacquot JP, Chartier Y, Meyer Y (1999) In vivo characterization of a thioredoxin $h$ target 
protein defines a new peroxiredoxin family. J Biol Chem 274:19714-19722

25. Chen L, Xie Q, Nathan C (1998) Alkyl hydroperoxide reductase subunit (AhpC) protects bacterial and human cells against reactive nitrogen intermediates. Mol Cell 1:795805

26. Rabilloud T, Berthier R, Vincon M, Ferbus D, Goubin G, Lawrence JJ (1995) Early events in erythroid differentiation: accumulation of the acidic Peroxiredoxin (PRP/ TSA/ NKEF-B). Biochem J 312:699-705

27. Shau H, Merino A, Chen L, Shih CCY, Colquohoun SD (2000) Induction of peroxiredoxins in transplanted livers and demonstration of their in vitro cytoprotection. Antioxid Redox Signal 2:347-354

28. Zhang P, Liu B, Kang SW, Seo, MS, Rhee SG, Obeid LM (1997) Thioredoxin peroxidase is a novel inhibitor of apoptosis with a mechanism distinct from that of Bcl-2. J Biol Chem 272:30615-30618

29. Kim H, Lee TH, Park ES et al. (2000) Role of peroxiredoxins in regulating intracellular hydrogen peroxide and hydrogen peroxide-induced apoptosis in thyroid cells. J Biol Chem 275:18266-18270

30. Ishii T, Yamada M, Sato H et al. (1993) Cloning and characterization of a $23-\mathrm{kDa}$ stress-induced mouse peritoneal macrophage protein. J Biol Chem 268:18633-18636

31. Kawai S, Takeshita S, Okazaki M, Kikuno R, Kudo A, Amann E (1994) Cloning and characterization of OSF-3, a new member of the MER5 family, expressed in mouse osteoblastic cells. J Biochem (Tokyo) 115:641-643

32. Iwahara S, Satoh H, Song DX et al. (1995) Purification, characterization, and cloning of a heme-binding protein $(23 \mathrm{kDa})$ in rat liver cytosol. Biochemistry 34:1339813406

33. Shau H, Butterfield LH, Chiu R, Kim A (1994) Cloning and sequence analysis of candidate human natural killerenhancing factor genes. Immunogenetics 40:129-134

34. Wen ST, Van Etten RA (1997) The PAG gene product, a stress-induced protein with antioxidant properties, is an Abl SH3-binding protein and a physiological inhibitor of cAbl tyrosine kinase activity. Genes Dev 11:2456-2467

35. Siow RC, Ishii T, Sato $\mathrm{H}$ et al. (1995) Induction of the antioxidant stress proteins heme oxygenase- 1 and MSP by stress agents and oxidised LDL in cultured vascular smooth muscle cells. FEBS Lett 368:239-242

36. Immenschuh $\mathrm{S}$, Iwahara $\mathrm{S}$, Satoh $\mathrm{H}$, Nell $\mathrm{C}$, Katz $\mathrm{N}$, Muller-Eberhard U (1995) Expression of the mRNA of heme-binding protein 23 is coordinated with that of heme oxygenase- 1 by heme and heavy metals in primary rat hepatocytes and hepatoma cells. Biochemistry 34:1340713411

37. Immenschuh S, Stritzke J, Iwahara S, Ramadori G (1999) Up-regulation of heme-binding protein 23 (HBP23) gene expression by lipopolysaccharide is mediated via a nitric oxide-dependent signaling pathway in rat Kupffer cells. Hepatology 30:118-127

38. Kim K, Kim IH, Lee KY, Rhee SG, Stadtman ER (1988) The isolation and purification of a specific "protector" protein which inhibits enzyme inactivation by a thiol/Fe (III)/O2 mixed-function system. J Biol Chem 263:47044711

39. Chae HZ, Kim IH, Kim K, Rhee SG (1993) Cloning, sequencing, and mutation of thiol-specific antioxidant gene of Saccharomyces cerevisiae. J Biol Chem 268:1681516821

40. Lim YS, Cha MK, Yun CH, Kim HK, Kim K, Kim IH (1994) Purification and characterization of thiol-specific antioxidant protein from human red blood cell: a new type of antioxidant protein. Biochem Biophys Res Commun 199:199-206

41. Shau H, Kim A (1994) Identification of natural killer enhancing factor as a major antioxidant in human red blood cells. Biochem Biophys Res Commun 199:83-88

42. Plishker GA, Chevalier D, Seinsoth L, Moore RB (1992) Calcium-activated potassium transport and high molecular weight forms of calpromotin. J Biol Chem 267:2183921843

43. Schröder E, Willis AC, Ponting CP (1998) Porcine naturalkiller-enhancing factor-B: oligomerisation and identification as a calpain substrate in vitro. Biochim Biophys Acta 1383:279-291

44. Harris JR, Schroder E, Isupov MN et al. (2001) Comparison of the decameric structure of peroxiredoxin-II by transmission electron microscopy and X-ray crystallography. Biochim Biophys Acta 1547:221-234

45. Cha MK, Kim IH (1995) Thioredoxin-linked peroxidase from human red blood cell: evidence for the existence of thioredoxin and thioredoxin reductase in human red blood cell. Biochem Biophys Res Commun 217:900-907

46. Kowaltowski AJ, Netto LE, Vercesi AE (1998) The thiolspecific antioxidant enzyme prevents mitochondrial permeability transition. Evidence for the participation of reactive oxygen species in this mechanism. J Biol Chem 273: 12766-12769

47. Sarafian TA, Verity MA, Vinters HV et al. (1999) Differential expression of Peroxiredoxin subtypes in human brain cell types. J Neurosci Res 56:206-212

48. Park SH, Chung YM, Lee YS et al. (2000) Antisense of human peroxiredoxin II enhances radiation-induced cell death. Clin Cancer Res 6:4915-4920

49. Krokowski M (1998) Diploma thesis: Characterization of 1-3 proteins against oxidative stress. Technical College, Berlin

50. Hessabi B, Schmidt I, Walther R (2000) The homeodomain of Nkx2.2 carries two cooperatively acting nuclear localization signals. Biochem Biophys Res Comm 270:695-700

51. Malaisse WJ, Malaisse-Lagae F, Sener A, Pipeleers DG (1982) Determinants of the selective toxicity of alloxan to the pancreatic B cell. Proc Natl Acad Sci USA 79:927-930

52. Gonzalez E, Rosello-Catafau J, Jawerbaum A et al. (2000) Pancreatic nitric oxide and oxygen free radicals in the early stages of streptozotocin-induced diabetes mellitus in the rat. Braz J Med Biol 33:1335-1342

53. Fujii T, Fujii J, Taniguchi N (2001) Augmented expression of peroxiredoxin VI in rat lung and kidney after birth implies an antioxidative role. Eur J Biochem 268:218-224

54. Watabe S, Kohno H, Kouyama H, Hiroi T, Yago N, Nakazawa T (1994) Purification and charaterization of a substrate protein for mitochondrial ATP-dependent protease in bovine adrenal cortex. J Biochem (Tokyo) 115: 648-654

55. Watabe S, Hasegawa H, Takimoto $\mathrm{K}$, Yamamoto $\mathrm{Y}$, Takahashi SY (1995) Possible function of SP-22, a substrate of mitochondrial ATP-dependant protease, as a radical scavenger. Biochem Biophys Res Commun 213: 1010-1016

56. Jaschke A, Mi H, Tropschug M (1998).Human T cell cyclophilin 18 binds to thiol-specific antioxidant protein Aop1 and stimulates its activity. J Mol Biol 277:763-769

57. Lee SP, Hwang YS, Kim YI et al. (2001) Cyclophilin a binds to peroxiredoxins and activates their peroxidase activity. J Biol Chem 276:29826-29832

58. Prosperi MT, Ferbus D, Rouillard D, Goubin G (1998) The pag gene product, a physiological inhibitor of c-abl tyrosine kinase, is overexpressed in cells entering $\mathrm{S}$ phase and 
by contact with agents inducing oxidative stress. FEBS Lett 423:39-44

59. Rabinovitch A, Suarez WL, Thomas PD, Strynadka K, Simpson I (1992) Cytotoxic effects of cytokines on rat islets: evidence for involvement of free radicals and lipidperoxidation. Diabetologia 35:409-413

60. Arnush M, Heitmeier MR, Scarim AL, Marino MH, Manning PT, Corbett JA (1998) IL-1 produced and released endogenously within human islets inhibits $\beta$-cell function. J Clin Invest 102:516-526

61. Kim AT, Sarafian TA, Shau H (1997) Characterization of antioxidant properties of natural killer-enhancing factor-B and induction of its expression by hydrogen peroxide. Toxicol Appl Pharmacol 147:135-142

62. Mitsumoto A, Takanezewa Y, Okawa K, Iwamatsu A, Nakagawa Y (2001) Variants of peroxiredoxins expression in response to hydroperoxide stress. Free Radic Biol Med 30:625-635

63. Lenzen S, Panten U (1988) Alloxan: history and mechanism of action. Diabetologia 31:337-342
64. Tiedge M, Lortz S, Munday R, Lenzen S (1998) Complementary action of antioxidant enzymes in the protection of bioengineered insulin-producing RINm5F cells against the toxicity of reactive oxygen species. Diabetes 47:1578-1585

65. Asahi M, Fujii J, Suzuki K et al. (1995) Inactivation of glutathione peroxidase by nitric oxide. J Biol Chem 270: 21035-21039

66. Bryk R, Griffin P, Nathan C (2000) Peroxynitrite reductase activity of bacterial peroxiredoxins. Nature 407:211-215

67. Berggren MI, Husbeck B, Samulitis B, Baker AF, Gallegos A, Powis G (2001) Thioredoxin peroxidase-1 (peroxiredoxin-1) is increased in thioredoxin-1 transfected cells and results in enhanced protection against apoptosis caused by hydrogen peroxide but not by other agents including dexamethasone, etoposide, and doxorubicin. Arch Biochem Biophys 392:103-109

68. Hotta M, Tashiro F, Ikegami H et al. (1998) Pancreatic beta cell-specific expression of thioredoxin, an antioxidative and antiapoptotic protein, prevents autoimmune and streptozotocin-induced diabetes. J Exp Med 188:1445-1451 